\title{
TECHNIQUES USED IN TRANSLATING MORAL AND RELIGION VALUES IN THE RAINBOW TROOPS
}

\author{
Cucu Mariam ${ }^{\left.a^{*}\right)}$, Yanti Suryanti ${ }^{\text {a) }}$ \\ a) Universitas Pakuan, Kota Bogor, Indonesia \\ ${ }^{*}$ e-mail korespondensi: cucumariam.unpak@gmail.com
}

\author{
Riwayat Artikel \\ diterima 01 Juni 2021 \\ direvisi 15 Juni 2021 \\ disetujui 28 Juli 2021
}

\begin{abstract}
.
The aims of this research is to find out the techniques that are used in translating the moral and religion values in literary text. The data of this research are taken from Laskar Pelangi and its translation The Rainbow Troops written by Andrea Hirata. The method used is content analysis with qualitative approach. The result of the research is that the moral values that are mostly found are hardworking and love; the religion values are loving Allah by doing all His command; and the techniques that are mostly used are free translation, substitution and omission. Although there are several sentences and content are omitted, the meaning and the values are still delivered completely to the readers.
\end{abstract}

Keywords: moral and religion values; free translation; substitution; omission

\section{PENGGUNAAN TEKNIK TRANSLASI NILAI MORAL DAN AGAMA PADA NOVEL LASKAR PELANGI}

\begin{abstract}
Tujuan penelitian ini adalah untuk menginvestigasi teknik yang digunakan untuk mentranslasi nilai moral dan agama pada teks literasi. Data pada penelitian ini diambil dari novel Laskar Pelangi atau dalam bahasa inggris The rainbow Troops yang ditulis oleh Andrea Hirata. Metode yang digunaan adalah analisis konten denganpendekatan kualitatif. Hasil dari penelitian ini adalah, nialai moral yang paling banyak ditemukan pada literatur ini adalah kerja keras dan kasih sayang; nilai agama yang didapat adalah cinta kepada Allah dengan mematuhi segala printahNya; teknik yang banyak ditemukan adalah translasi bebas, subtitusi dan kelalaian.Meskipun terdapat beberapa kalimat dan konten yang dihilangkan, makna dan nilai masih tetap tersampaikan secara utuh kepada pembaca.
\end{abstract}

Kata Kunci: Nilai Moran dan Agama, Translasi Bebas, Substitusi, Kelalaian.

\section{INTRODUCTION}

Translation is the replacement of an original text with another text (House, 2009: 3). It mediates between languages, societies and literatures and it also overcomes the linguistic and cultural barriers. Through translation, the communicative events are reduplicated, so that it is usually called a secondary communication. Besides, through translation people can access something, some message from another resource originally written or spoken in another language or other languages. In other words, translation is the process of replacing an original text or the source text with a substitute one or the target text.

According to House (2009: 4) there are three kinds of translation process, they are interlingual translation, intralingual translation, and intersemiotic translation. The first one is that the message in the source language text is rendered as a target text in a different language. The second one is that the text in one variety of the language is reworded into another, for example, the text written in Old English is transferred into Modern English. The last one is not related to language, but it is another form of translation, for example the poem translated into a dance or opera.

When a text in the source language is translated into the target language, such as Bahasa Indonesia into English, the translator must pay attention to some points: who is the reader of the result of the translation, the aim or the aims, and something that is translated is the message or the content of the text. Thus, the result must be equivalent between the target and the source language (Hoed, 2006: 52). Based on that, the translator or interpreter must know the methods, techniques and approaches in translating the texts. However, the focus of this article is the techniques used to translate the moral and religious values that are found in The Troops novel written by Andrea Hirata. As we know that this novel is one the best novels written in Bahasa Indonesia in which it arises a lot of those Indonesian two values.

Based on the background of the research, the question arises is what techniques are mostly used in translating the values in The Rainbow Troops? Moral Values

Moral values are really related to character education that will influence the quality of human resources in one area or country. The good human resources with good character or moral and good religion will be able to compete globally. The moral values will protect people from doing corruption, environmental damage, dishonesty, and disobedience of the government and society rules. Based on Kurniasih and Sany (2017: 7) there are nine basic character that become the goals of character education, they are (1) love Allah, (2) responsible, discipline and independent, (3) honest, (4) respect and polite, (5) love, care, and cooperative, (6) confidents, creative, hardworking and persistent, (7) fair and leadership, (8) nice and modest, (9) tolerant, love peace and unity.

When we are translating the text, we do not only transfer the words but also the values and the culture found in the text. To get the right translation, the translator has to pay attention to the techniques that must be used in order that the 
content are suitable to the original text. According to Moentaha (2006: 48 - 83) there are eight kinds of translating techniques:

1. Literal translation: the translation that is done in words level. That is the translation of word by word. It gives the information from SL to TL by following the norms of TL. This technique can be used if the arrangement of the text in SL is very simple, and the result of the translation is adequate.

2. Substitution: It is rarely used. It is called automatic or machine translation. The translation using this technique is based on the formal equivalence of SL and TL and the meaning. It only has one term of the translated word. It also happens in the word level and it has the similarity with the literal translation.

3. Free translation: the translation in language categories, such as sentence or text, the whole text. It is better accepted than literal translation. It is because in this technique the meaning deviation and violation of TL do not happen. The weakness of this technique is the information given in the TL is not the equivalence of the SL, but the equivalence of the situation.

4. Paraphrase: Situation equivalence also happens in this technique. It is because the information in the SL is maintained of its situation, instead of the meaning of SL text. Thus, the translator needs to know the real situation drawn in the SL text. The real situation often becomes the key to show the real meaning of the situation drawn.

5. Replacement: In translation, replacement technique is used to translate the grammatical categories, lexical categories, and sentence construction. It consists of (a) the change of word classes; (b) the change of parts of sentences; (3) Lexical change; (4) Antonym translation; (5) compensation.

6. Additions: Lexical addition in TL is needed to show the meaning of SL text is transferred using another means, including the grammatical means, but it does not change or add the meaning of the SL text.

7. Omissions or Dropping: It removes the abundant or redundant words, but the content of the information of the SL text is still complete.

8. Compression: the translation is short and concise by doing the lexical reduction.

9. Syntactic derivation: the process of constructing syntactic forms through the main construction transformation. It changes the position of one sentence into another. E.g. passive into active forms, positive sentence into negative sentence.

10. Descriptive translation: the translation that deliver the meaning of SL text into the TL text that uses the combination of free words. It describes the specific reality of one country that does not have any equivalence in TL.

11. Explication/Implication: It realizes the explicit meaning of the TL because the SL text is not clear. The result of the translation will make the meaning clear and easy to understand.
The method that is used in this research is content analysis using qualitative approach which can give a valid conclusion from the text and context (Krbeacippendroff in Emzir, 2011). The reason using content analysis is because the data is two written novels Laskar Pelangi and its translation The Rainbow Troops written by Andrea Hirata. The content analysis used in this research is to find out the techniques used in translating the moral and religion values written in the original novel Laskar Pelangi.

The research design is descriptive analysis to describe the techniques in Bahasa Indonesia and English translation in The Rainbow Troops. The technique to collect the data is documentation technique in which the researchers will do some steps: reading the two novels Laskar Pelangi and The Rainbow Troops, identifying moral and religious values, identifying their translations, and identifying the techniques used in translating the values.

\section{DISCUSSION}

The moral values that are found are sympathy, love, attention, politeness, hardworking, care, responsibility, honor, persistence, fairness, democracy, honesty, and patience. We can see that

The most frequent moral values appear are hardworking and love. It means that the moral values that are shown in the novel is giving the examples of how the characters do their live although they are living poor with the restricted facilities and finance. Meanwhile the religion values found are love to Allah, always do and follow God's command (tawakal). The religion values are based on moslem values which are based on Al-Quran and sunnah of Prophet Mohammad. The words used that show the hardworking are ...keberanian pantang menyerah melawan kesulitan, keinginan kuat untuk mencapai cita-cita, secara konsisten ia berusaha mencapainya. The words that show love are Kasihan ayahku, telah membuat kami menyayangi sekolah ini, ....sangat lembut jika berhadapan dengan Harun. The words that show the religion values are shalatlah tepat waktu, pada pertanggung jawaban setelah mati nanti, menyitir perkataan khalifah...

The Techniques that are used in translating the moral and religion values in this novel are free translation, substitution, omission, paraphrase and replacement. 


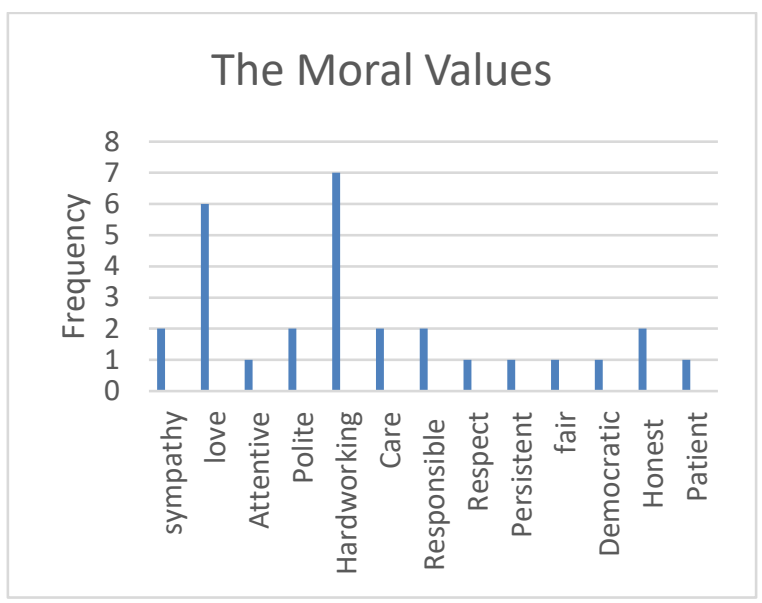

Figure 1. The Moral Value in Rainbow Troops Text

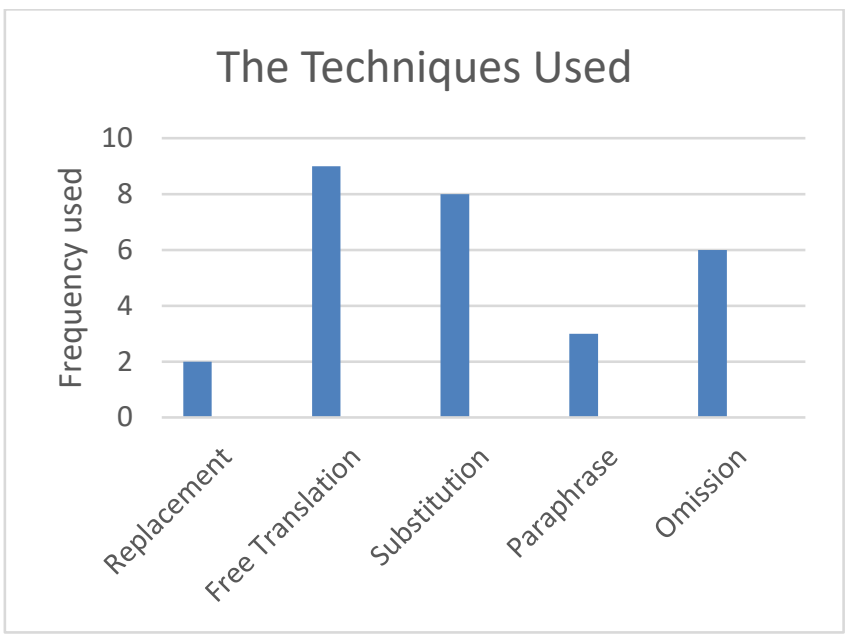

Figure 2. The Technique Used in Rainbow Troops Text

From the table above we can see that free translation techniques, substitution and omission are mostly used. The following are the examples of those three techniques:

TABLE1. The Example of Three Technique

\begin{tabular}{|c|c|c|c|}
\hline NO & BAHASA & ENGLISH & TECHNIQUES \\
\hline 1 & $\begin{array}{c}\text { Kasihan } \\
\text { ayahku. Maka } \\
\text { aku tak sampai } \\
\text { hati } \\
\text { memandang } \\
\text { wajahnya. P. } \\
\text { 3, P. } 5 \\
\end{array}$ & $\begin{array}{l}\text { My poor } \\
\text { father. I } \\
\text { didn't have } \\
\text { the heart to } \\
\text { look him } \\
\text { in the eye. } \\
\text { P. } 4 \text { P. } 6\end{array}$ & $\begin{array}{c}\text { Replacement } \\
\text { and free } \\
\text { translation }\end{array}$ \\
\hline 2 & $\begin{array}{l}\text { Para orang tua } \\
\text { menepuk- } \\
\text { nepuk } \\
\text { bahunya untuk } \\
\text { membesarkan } \\
\text { hatinya. } \\
\text { P. } 6 \text { P.17 }\end{array}$ & $\begin{array}{c}\text { The } \\
\text { parents } \\
\text { patted him } \\
\text { on the } \\
\text { back to } \\
\text { console } \\
\text { him. } \\
\text { P. } 6 \text { P.13 }\end{array}$ & Substitution \\
\hline 3 & $\begin{array}{c}\text { Sahara selalu } \\
\text { sabar }\end{array}$ & $\begin{array}{c}\text { Sahara } \\
\text { patiently }\end{array}$ & Omission \\
\hline
\end{tabular}

\begin{tabular}{|c|c|c|c|}
\hline NO & BAHASA & ENGLISH & TECHNIQUES \\
\hline & $\begin{array}{l}\text { mendengarkan } \\
\text { cerita itu } \\
\text { walaupun } \\
\text { Harun } \\
\text { menceritakann } \\
\text { ya setiap hari, } \\
\text { berulang- } \\
\text { ulang, puluhan } \\
\text { kali, sepanjang } \\
\text { tahun, dari } \\
\text { kelas } 1 \text { SD } \\
\text { sampai dengan } \\
\text { kelas } 3 \text { SMP. } \\
\text { Sahara tetap } \\
\text { setia } \\
\text { mendengar- } \\
\text { kan. } \\
\text { P. } 77 \text { P. } 46\end{array}$ & $\begin{array}{l}\text { listened, } \\
\text { even } \\
\text { though } \\
\text { Harun told } \\
\text { this story } \\
\text { every day, } \\
\text { over again, } \\
\text { thousands } \\
\text { of times, } \\
\text { all year } \\
\text { around, } \\
\text { year after } \\
\text { year. } \\
\text { P. } 38 \text { P. } 28\end{array}$ & \\
\hline
\end{tabular}

Besides the three techniques, replacement and paraphrase are also found. Some sentences in Bahasa that show moral values are not translated, and they belong to omission. Although they are omitted, the whole meaning of the original text are still able to catch, and the values are still easy to deliver to the reader.

\section{CONCLUSION}

This novel has a lot of moral values that are good for teachers and students. The moral values that are mostly found in this novel are hardworking and love, the religion value is loving to Allah and always try to do the worship and life based on the command of Allah and Prophet Mohammad. It means that the values are suitable to the aims of character education in Indonesia. Meanwhile, the techniques that are mostly used in The Rainbow Troops are free translation, substitution and omission. Some sentences are translated freely, some sentences are omitted and some sentences are substituted by using the rules and words of the target language, English.

\section{REFERENCES}

Emzir. (2011). Metodologi Penelitian Kualitatif: Analisis Data. Jakarta: Rajawali Press.

Hirata, Andrea. (2006). Laskar Pelangi. Yogyakarta: Bentang Pustaka.

Hirata, Andrea (2009). The Rainbow Troops. Diterjemahkan oleh Angie Kilbane. Yogyakarta: Bentang Pustaka.

Hoed, Hoedoro Benny. (2006) Penerjemahan dan Kebudayaan. Jakarta: Pustaka Jaya.

House, Juliane. (2009) Translation. Oxford: Oxford University Press. 
Kurniasih Imas and Sani Berlin. 2017. Pendidikan

Karakter: Internalisasi dan Metode

Pembelajaran di Sekolah. Jakarta: Penerbit

Kata Pena.

Moentaha, Salihen. 2006. Bahasa dan Terjemahan:

Language and Translation The New

Millennium Publication. Jakarta: Kesaint

Blanc. 